DOI https://doi.org/10.30525/978-9934-26-111-4-13

\title{
ФОРМУВАННЯ ЕФЕКТУ СВІДКА ПРИ СУМІСНОМУ ПРОРОЩУВАННІ ОПРОМІНЕНОГО І НЕОПРОМІНЕНОГО НАСІННЯ ЦИБУЛІ В СПІЛЬНОМУ ВОДНОМУ СЕРЕДОВИЩІ
}

\author{
Герман О. Ю.
}

кандидат біологічних наук, дочент кафедри генетики і циттології

Харківський національний університет імені В. Н. Каразіна

\section{Орлова Н. О.}

студентка кафедри генетики і циитології

Харківський національний університет імені В. Н. Каразіна

Плужник А. О.

студентка кафедри генетики і цчитології

Харківський національний університет імені В. Н. Каразіна м. Харків, Україна

Пряму дію радіації на живі організми досліджено досить повно. Але існують немішенні прояви радіаційного впливу, коли зміни в генетичному апараті i клітинному метаболізмі відбуваються в неопромінених клітинах і тканинах, які перебувають в безпосередній близькості від опромінених, або знаходились поруч із опроміненими в момент дії радіаційного фактору, що і $\epsilon$, власне, ефектом свідка. Явище ефекту свідка було відкрите і тривалий час досліджувалось саме на клітинному рівні [1]. Але останнім часом з'являються роботи, в яких ефект свідка показаний ї на міжорганізменому рівні [2].

Необхідність врахування дистанційних, немішенних ефектів іонізуючої радіації при плануванні експериментів 3 опроміненими клітинами і організмами, проведенні радіаційної терапії пухлин, оцінці радіаційного навантаження обумовлює актуальність досліджень в цієї області.

Мета роботи полягала в дослідженні можливості індукції ефекту свідка в кореневій меристемі проростків інтактного насіння цибулі при сумісному його пророщуванні 3 насінням, опроміненим гаммарадіацією в дозі 40 Гр. 
Повітряно сухе насіння двох сортів цибулі Allium сера L. (Глобус і Мавка селекції Інституту овочівництва і баштанництва УААН) опромінювали гамма-радіацією Со $^{60}$ в Харківському національному університеті імені В.Н Каразіна в дозі 40 Гр. В експерименті були варіанти: К - контроль - неопромінене насіння; 40 Гр - насіння, опромінене гамма-радіацією в дозі 40 Гр; К + 40 Гр - режим ефекту свідка: спільне пророщування контрольного насіння і опроміненого дозою 40 Гр в одному водному середовищі. Фіксацію корінців проростків в оцтовому алкоголі проводили на 66-ту і 90-ту години росту. На цитологічних препаратах меристеми аналізували мітотичну активність, кількість хромосомних мутацій і мікроядер. Для порівняння контрольної і експериментальної вибірок використовували F-критерій. Перевірку нульової гіпотези проводили на рівні значущості р $<0,05$ [3].

Результати обліку мітотичної активності. Рівень мітотичної активності $€$ інформативним показником при оцінці впливу факторів оточення на організм, зокрема рослинний. Успішний розподіл клітини залежить від координації багатьох процесів, що регулюються геномом. Вплив зовнішніх факторів може як пригнічувати, так і стимулювати мітотичну активність. Появу перших мітозів в кореневій меристемі проростків спостерігали вже на 66-тій годині початкового росту. В цей строк мітотична активність становила $3,2-3,6 \pm 0,5 \%$ у обох сортів. По мірі зростання проростків інтенсивність проліферації збільшувалася i вже на 90-ту годину росту в меристемі проростків сорту Глобус $6,3 \pm 0,7 \%$, а у Мавки $-5,5 \pm 0,6 \%$ клітин ділилися.

Відомо про стимуляцію мітотичної активності під впливом малих доз іонізуючої радіації, до яких відноситься і доза 40 Гр для цибулі. Це явище відноситься до проявів радіаційного гормезису и було продемонстровано на ряді біологічних об'єктів [4]. Ефект стимуляції мітотичної активності в варіанті 40 Гр спостерігали лише у проростків сорту Мавка на 90-тій годині росту.

Оцінювання формування ефекту свідка проводили порівнюючи дані, отримані в контролі і у варіанті $К+40$ Гр. На ранньому строці спостереження, сумісне пророщування опроміненого і неопроміненого насіння сприяло підвищенню значень мітотичних індексів у варіанті К + 40 Гр. На 66-тій годині росту у обох сортів вони дорівнювали 5,0$5,5 \pm 0,6 \%$, що перевищувало контроль в 1,5 рази. Це співвідношення значень мітотичних індексів дослідного i контрольного варіантів зберіглось і в наступний строк спостереження. Значення мітотичних 
індексі в варіанті з сумісним пророщуванням інтактного і опроміненого насіння були максимальними з усіх досліджених і становили 9,4 $\pm 0,8 \%$

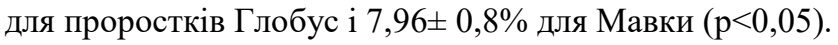

Отже, можна зробити висновок про формування ефекту свідка у проростків неопроміненого насіння при сумісному їх пророщуванні 3 опроміненими за критерієм стимуляції мітотичної активності.

Аналіз рівня хромосомного мутагенезу. Облік хромосомних мутацій проводили анафазним методом. Серед хромосомних мутацій в меристемі досліджуваних рослин зустрічались хроматидні і хромосомні мости, фрагменти.

Рід Allium відносять до радіочутливих, бо для його представників властивий високий рівень спонтанного мутагенезу. Але різні види в межах роду, i навіть різні сорти, мають різну чутливість [5]. Досліджувані сорти характеризувалися близьким рівнем спонтанного мутагенезу при спостереженні в ранні строки проростання насіння. На 66-ій годині росту кількість клітин з хромосомними абераціями у обох сортів становила 9-11\%. Але із збільшенням строку росту, зі збільшенням мітотичної активності, частка клітин з патологіями мітозу майже не змінилася у проростків Глобус і зросла в 2 рази у проростків Мавка $(\mathrm{p}<0,05)$.

Опромінення збільшувало частку клітин з абераціями у обох сортів до $20-22 \%$ i цей підвищений рівень хромосомного мутагенезу відзначали в обидва строки спостереження. Відомо, що зменшення частки клітин 3 абераціями хромосом відбувається як за рахунок репаративних процесів, так і за рахунок репопуляції, коли найбільш пошкоджені клітини гинуть, а кількість клітин в тканині відновлюється за рахунок розмноження тих клітин, що постраждали найменше. В даному експерименті інтервал часу між двома спостереженнями складав 24 години. В середньому тривалість мітотичного циклу у клітин меристеми відповідає 20-24 годинам. Виходячи 3 того, що кількість хромосомних аберацій в обидва строки спостереження була приблизно однаковою, можна заключити, що системи репарації не встигли за цей період ефективно видалити всі пошкодження i відновлювальні процеси потребують більше часу.

Пророщування насіння сумісно 3 опроміненими спричинило тенденцію до появи додаткової до контрольної кількості хромосомних мутацій. В меристемі варіанту $\mathrm{K}+40$ Гр клітин 3 пошкодженнями хромосом було на 3-4\% більше, ніж в контролі. Слід зазначити, що 3 
плином часу кількість хромосомних мутацій в варіанті К +40 Гр не змінилася, тоді як в контролі у сорту Мавка їх кількість зросла.

Результати мікроядерного тесту. Мікроядра утворюються 3 ацентричного хромосомного матеріалу, який в попередньому досліджуваному мітотичному циклі не потрапив в основне ядро наприкінці телофази.Найменша кількість клітин 3 мікроядрами було зареєстрована в контролі на 66-ій годині росту. На 90-тій годині кількість мікроядер не змінилась у проростків сорту Глобус і зросла у проростків Мавка в три рази $(\mathrm{p}<0,05)$.

Опромінення насіння дозою 40 Гр збільшило кількість клітин 3 мікроядрами. Найбільш суттєве збільшення відбулось в меристемі сорту Мавка на 90-ій годині росту. Слід зазначити, що кількість хромосомних мутацій, обчислена анафазним методом, i рівень мітотичної активності у цього сорту також перевищували аналогічні показники Глобуса. Зазвичай тканини 3 інтенсивної проліферацією більш здатні до репопуляції. Отже доцільним $є$ пролонговане дослідження цих показників, бо можна допустити зниження рівня аномалій мітозу при подальшому розвитку рослинного організму.

Ефект свідка чітко простежувався у обох сортів протягом всього строку спостереження. Кількість клітин з мікроядрами в варіанті К +40 Гр стабільно була вищою за контроль, і в деяких варіантах вищою за варіант 40 Гр.

Незважаючи на достатню кількість досліджень ефекту свідка в науковій літературі не сформовано чіткої картини щодо механізмів цього явища. Існують докази, що опромінені клітини секретують певні фактори в середовище і подальша інкубація неопромінених клітин в цьому середовищі призводить до змін в їх життєдіяльності. Припускають, що такими факторами можуть бути цитокіни в тваринних клітинах, активні форми кисню [1].

Збільшення рівня хромосомного мутагенезу у варіантах з сумісним пророщуванням опроміненого i інтактного насіння може бути викликане дією цих активних форм кисню. Можна припустити, що системи репарації клітин проростків інтактного насіння не були активовані дією опромінення і не ліквідують пошкодження належним чином.

Отже можна заключити, стимуляція інтенсивності клітинної проліферації під впливом малих доз опромінення залежить від часу спостереження і від генотипу організму; індукція ефекту свідка 
відбувається у проростків неопроміненого насіння при сумісному їх пророщуванні з проростками опроміненого гамма-радіацією в дозі 40 Гр насіння як підвищення рівня мітотичної активності; в умовах сумісного пророщування опроміненого i iнтактного насіння збільшується кількість хромосомних аберацій і мікроядер в меристемі проростків інтактного насіння.

\section{Лiтература:}

1. Little J.B. Genomic instability and bystander effects: a historical perspective. Oncogene. 2003. V. 22. P. 6978-6987.

2. Choi V. W. Y., Ng C. Y. P., Kobayashi A., Konishi T., Suya N., Ishikawa T., Cheng S. H., Yu K. N. Bystander Effect between Zebrafish Embryos in Vivo Induced by High-Dose X-rays. Environ. Sci. Technol. 2013. V. 47. P. 6368 - 6376. doi.org/10.1021/es401171h.

3. Атраментова Л.О., Утєвська О.М. Статистичні методи в біології. Харків: ХНУ імені В.Н. Каразіна. 2007. 288 с.

4. Brenner D.J. Low Radiation Doses: Small Risks? No Risks? Or Risks to Only a Few? Radiology. 2020. Vol. 295. № 2. P:446-447.

5. Leme D.M., Marin-Morales M.A.. Allium cepa test in environmental monitoring: A review on its application. Mutation Research/Reviews in Mutation Research. 2009. V. 682. № 1. P. 71-81. 